\title{
NGHIÊN CÚU ĐO LƯờNG BÃO HÒA OXY MÁU TĨNH MẠCH TRỘN S̄̄o Ở BỆNH NHÂN PHẪU THUẬT TIM CÓ NGUY CƠ CAO
}

\author{
Đoàn Đúc Hoằng*, Nguyễn Thị Đoan Trang*, \\ Đinh Ngọc Huân*, Phan Thị Hạnh*, Luu Thị Minh Đức*
}

\section{TÓM TẮT}

Sử dụng catheter Swan-Ganz để khảo sát giá trị của chỉ số $\mathrm{S} \overline{\mathrm{O}} \mathrm{O}_{2}$ và đánh giá kết quả hồi sức huyết động trên 112 bệnh nhân phẫu thuật tim có nguy cơ cao bao gồm các biến số nghiên cứu:chỉ số bão hòa oxy máu tĩnh mạch trộn $\mathrm{S}_{\overline{0}} \mathrm{O}_{2}$; thời gian thở máy; thời gian điều trị tại ICU. Giá trị của chỉ số $\mathrm{S} \mathrm{O}_{2}$ ở những bệnh nhân phẫu thuật tim có nguy cơ cao có biến thiêngiảm dần (nhưng đảm bảo $\left.\mathrm{SV}_{\mathrm{V}}-\mathrm{TB}>55 \%\right)$ từ thời điểm trước mổ $\left(\mathrm{T}_{0}\right)$ đến sau mổ $\left(\mathrm{T}_{\text {off }}\right)$ với $\mathrm{p}<0,001$. Kết quả về thời gian thở máy ngắn nhất là 5 giờ, dài nhất là 192 giờ ( 08 ngày), trung bình là 22,56 giờ; trong đó $93,8 \%$ có thời gian thở máy $\leq 48 \mathrm{~h}$; và $6,2 \%$ có thời gian thở máy $>48 \mathrm{~h}$. Thời gian điều trị ở hồi sức ngắn nhất là 18 giờ, dài nhất 240 giờ (10 ngày), thời gian trung bình là 50,88 giờ; trong đó $92,9 \%$ bệnh nhân có thời gian điều trị ở hồi sức $\leq 72 \mathrm{~h}$, và $7,1 \%$ bệnh nhân có thời gian điều trị ở hồi sức kéo dài trên $>72 \mathrm{~h}$. Giá trị của chỉ số $\mathrm{SV} \mathrm{O}_{2} \geq 55 \%$ là chỉ điểm tiên lượng tốt về điều trị huyết động cho những bệnh nhân phẫu thuật tim có nguy cơ cao, đảm bảo duy trì cân bằng cung cầu oxy ở giai đoạn hồi sức sau mố tim.Hồi sức huyết động dưới hướng dẫn bởi chỉ số $\mathrm{S} \overline{\mathrm{O}} \mathrm{O}_{2}$ ở những bệnh nhân này giúp cải thiện với giảm thời gian thở máy, và thời gian điều trị hồi sức.

\section{SUMMARY}

Using the Swan-Ganz catheter to mesure $\mathrm{S}_{\overline{\mathrm{V}}}{ }_{2}$ and evaluate the hemodynamic outcomes in 112 high risk cardiac surgical patients. The variables are $\mathrm{SV}_{\mathrm{V}} \mathrm{O}_{2}$ indice; ventilation duration; and ICU stay. The variation of $\mathrm{S} \overline{\mathrm{V}} \mathrm{O}_{2}$ values in high risk cardiac surgical patients was regressive (but mean values $>55 \%$ )from preoperation $\left(\mathrm{T}_{0}\right)$ to postoperation $\left(\mathrm{T}_{\text {off }}\right) ; \mathrm{p}<0,001$. The minimal ventilation duration was 5 hours, the maximal ventilation duration was 192hours (8 days), the average duration was 22,56 hours. $93,8 \%$ patients had the ventilation duration less than 48hours; and 6,2\% patients had the ventilation durationmore than 48hours. The minimal ICU stay was 18 hours, the maximal ICU stay was 240 hours (10days), the average ICU stay was 50,88 hours. $92,9 \%$ patients had the ICU stay less than 72 hours; and 7,1\% patients had the ICU stay more than 71hours. $\mathrm{SV} \mathrm{O}_{2}$ value $\geq 55 \%$ was the approval prediction in stable hemodynamic state in high risk cardiac surgical patients for maintaining the balance between oxygen delivery and oxygen consumption in postoperation periods. The treatment guided by $\mathrm{S} \overline{\mathrm{V}} \mathrm{O}_{2}$ monitoring in there patients helping to reduce the ventilation duration, and the ICU stay.

\section{I. ĐẠTT VẤN ĐỀ}

Bão hòa oxy máu tĩnh mạch trộn $\mathrm{S} V \overline{O_{2}}$ là một chỉ số lý tưởng để đánh giá tình trạng huyết động bởi vì nó cung cấp thông tin về tình trạng của hệ thống cung cấp oxy cho cơ thể người [1].SV̄ $\mathrm{O}_{2}$ phụ thuộc vào cung lượng tim $(\mathrm{CO})$, bão hòa oxy máu động mạch $\left(\mathrm{SaO}_{2}\right)$, và khả năng vận chuyển oxy của dòng máu (hemoglobin, $\mathrm{Hb}$ ), và nhu cầu tiêu thụ oxy $\left(\mathrm{VO}_{2}\right)$ [2].

Mặc dù thông số $\mathrm{S} V \overline{O_{2}}$ đã được sử dụng rộng rãi để theo dõi trong quá trình phẫu thuật, nhưng số lượng các nghiên cứu đánh giá về lợi ích của $\mathrm{SV}_{\mathrm{V}} \mathrm{O}_{2}$ trong phẫu thuật tim vẫn còn khá hạn chế. Với mong muốn đạt hiệu quả cao trong hồi sức huyết động góp phần nâng cao chất lượng phẫu thuật điều trị bệnh lý tim mạch, chúng tôi triển khai đề tài"Nghiên cứu đo lưò̀ng các chi số oxy hóa trong hồi sức huyết động ở bệnh nhân phẫu thuật tim nguy co cao"với mục tiêu:

1. Khảo sát sự biến thiên giá trị của các chỉ số $\mathrm{SV} \mathrm{O}_{2}$ ở những bệnh nhân phẫu thuật tim có nguy cơ cao;

2. Nghiên cứu mối tương quan giữa giá trị chỉ số $\mathrm{S} \overline{\mathrm{O}} \mathrm{O}_{2}$ và kết quả hồi sức huyết động ở các bệnh nhân phẫu thuật tim có nguy cơ cao. \section{CÚU \\ II. ĐỐI TƯợNG VÀ PHƯƠNG PHÁP NGHIÊN}

\section{1. Đối tượng nghiên cứu}

Nghiên cứu của chúng tôi gồm 112 bệnh nhân tuổi trên 16 được phẫu thuật tim có nguy cơ cao tại $\mathrm{BV}$ Trung ương Huế

2.1.1.Nguy co trước phẫu thuật: bao gồm những bệnh nhân có chỉ định phẫu thuật điều trị bệnh lý van tim hoặc bệnh động mạch vành có tổn thương nghiêm

* Bệnh viện Trung urong Hué

Người chịu trách nhiệm khoa học: Ths. Đoàn Đức Hoằng

Ngày nhận bài: 18/06/2016 - Ngày Cho Phép Đăng: 18/08/2016

Phản Biện Khoa học: PGS.TS. Đặng Ngọc Hùng GS.TS. Lê Ngoc Thành 
trọng chức năng tim hoặc chức năng cơ quan trước mổ có tiêu chuẩn sau [7], [8]:

- Phân độ suy tim theo NYHA $\geq$ III.

- Phân suất tống máu thất trái giảm $\mathrm{EF} \leq 50 \%$.

- Tăng áp phổi, áp lực động mạch phổi tâm thu $\mathrm{PASP} \geq 55 \mathrm{mmHg}$.

- Nhồi máu cơ tim mới trong vòng 90 ngày trở lại.

- Suy thận với creatinine huyết thanh $\geq 200$ mmol/L, hoặc bệnh kèm khác khả năng ảnh hưởng huyết động sau mổ.

2.1.2. Nguy co do tác động phẫu thuật: gồm những phẫu thuật điều trị bệnh van tim hoặc bệnh động mạch vành có tiên lượng thực hiện kỹ thuật ngoại khoa phức tạp kéo dài, có thể ảnh hưởng chức năng tim nghiêm trọng [9]:

- Bệnh lý van tim có chỉ định phẫu thuật can thiệp từ 2 đến 3 van.

- Bệnh động mạch vành cần phẫu thuật từ 3 cầu nối chủ vành trở lên.

- Phẫu thuật can thiệp bệnh lý van tim kết hợp làm cầu nối chủvành.

- Phẫu thuật tim lần 2 trở lên.

- Phẫu thuật tim cấp cứu.

2.2. Phương pháp nghiên cứu: sử dụng catheter Swan-Ganz để khảo sát giá trị các chỉ số $\mathrm{S}_{\bar{V}} \mathrm{O}_{2}$ và đánh giá kết quả hồi sức huyết độngvề thời gian thở máy và thời gian điều trị tại ICU

\section{KẾT QUẢ NGHIÊN CÚU}

\section{1. Đặc điểm của nhóm nghiên cứu}

- Đặc điểm chung

Phân bố giới tính, độ tuổi và bệnh lý tim mạch

\begin{tabular}{|c|c|c|c|c|c|c|c|}
\hline Giới, tuổi & $\bar{X} \pm \mathrm{SD}$ & $\mathrm{N}$ & $\%$ & \multicolumn{2}{|c|}{ Bệnhvan tim } & \multicolumn{2}{|c|}{ Bệnh mạch vành } \\
\hline Nam & $46,43 \pm 13,53$ & 44 & 39,3 & \multirow{2}{*}{$\mathrm{n}$} & \multirow{2}{*}{$\%$} & \multirow{2}{*}{$\mathrm{n}$} & \multirow{2}{*}{$\%$} \\
\hline Nữ & $46,85 \pm 12,00$ & 68 & 60,7 & & & & \\
\hline$<60$ & $43,43 \pm 10,26$ & 96 & 85,7 & \multirow{3}{*}{108} & \multirow{3}{*}{96,4} & \multirow{3}{*}{4} & \multirow{3}{*}{3,6} \\
\hline$\geq 60$ & $66,25 \pm 5,11$ & 16 & 14,3 & & & & \\
\hline Chung & $46,69 \pm 12,57$ & 112 & 100 & & & & \\
\hline
\end{tabular}

Nhận xét: Nam chiếm tỷ lệ thấp 39,3\%, nữ chiếm tỉ lệ cao hơn $60,7 \%$; nhóm tuổi <60 chiếm đa số 85,7\%, nhóm tuổi $\geq 60$ chiếm tỉ lệ $14,3 \%$; tuổi trung bình của nhóm nghiên cứu là 46,69 $\pm 12,57$ tuổi (lớn nhất là 78 tuổi, nhỏ nhất là 18 tuổi); bệnh lý van tim chiếm đa số so với bệnh mạch vành (96,4\% so với 3,6\%).

- Đặc điểm các yếu tố nguy cơ truớc mổ tim

Các yếu tố nguy cơ trước mổ tim

\begin{tabular}{|l|c|c|}
\hline \multicolumn{1}{|c|}{ Yếu tố nguy cơ } & $\mathrm{N}$ & $\%$ \\
\hline Suy tim trước mổ (NYHA.III-IV) & 91 & 81,3 \\
\hline Phân suất tống máu giảm EF < 50\% (max=67; min=30) & 36 & 32,1 \\
\hline Tăng áp phổi nặng PASP $\geq 55$ mmHg & 31 & 27,7 \\
\hline Nhồi máu cơ tim mới trong vòng 90 ngày & 4 & 3,6 \\
\hline Bệnh lý kèm có tổn thương chức năng cơ quan (thận, gan) & 10 & 8,9 \\
\hline Tuổi $\geq 60$ & 16 & 14,3 \\
\hline
\end{tabular}

Có 81,3\% bệnh nhân suy tim nặng trước mổ (NYHA.III-IV); 32,1\% giảm phân suất tống máu thất trái (thấp nhất $\mathrm{EF}=30 \%) ; 27,7 \%$ tăng áp phổi nặng $(\geq 55 \mathrm{mmHg})$; có 4 bệnh nhân $(3,6 \%)$ bị nhồi máu cơ tim mới trước mổ; $8,9 \%$ giảm chức năng tạng (thận, gan) trước mổ tim; tuổi $\geq 60$ tuổi chiếm tỷ lẹ̣ 14,3\%. 
- Đặc điểm phân bố các loại hình phẫu thuật tim

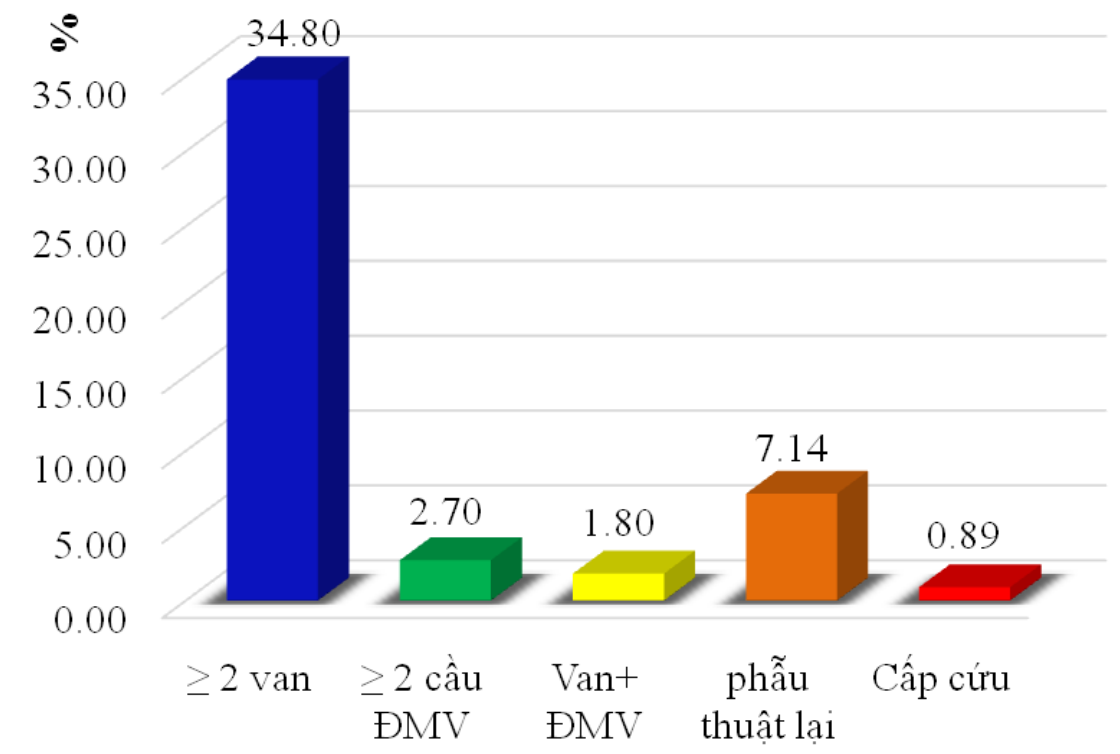

\section{Biểu đồ 3.2. Đặc điểm phân bố các loại hình phẫu thuật tim}

Nhận xét: 34,80\% phẫu thuật can thiệp đồng thời từ 02 van tim trở lên, 7,14\% phẫu thuật tim lần 2 hoặc lần $3 ; 2,7 \%$ phẫu thuật can thiệp $\geq 02$ cầu nối động mạch vành, $1,8 \%$ phẫu thuật vừa van tim và bắc cầu vành.

\subsection{Kết quả đo lường các chỉ số các chỉ số oxy hóa}

- Chỉ số bão hòa oxy hóa tĩnh mạch trộn $\mathrm{S} \bar{v} \mathrm{O}_{2}$

Kết quả đo lường bão hòa oxy máu tĩnh mạch trộn $\mathrm{S} \mathrm{O}_{2}$

\begin{tabular}{|c|c|c|c|c|}
\hline $\mathrm{S} \overline{\mathrm{V}} \mathrm{O}_{2}(\%)$ & $\mathrm{T}_{0}$ & $\mathrm{~T}_{2}$ & $\mathrm{~T}_{8}$ & $\mathrm{~T}_{\text {off }}$ \\
\hline $\mathrm{S} \overline{\mathrm{V}} \mathrm{O}_{2} \mathrm{~min}$ & 56 & 40 & 40 & 40 \\
\hline $\mathrm{S} \overline{\mathrm{V}} \mathrm{O}_{2} \mathrm{max}$ & 89 & 91,9 & 90,2 & 92 \\
\hline $\mathrm{S} \overline{\mathrm{V}} \mathrm{O}_{2}-\mathrm{TB}$ & $73,97 \pm 7,75$ & $68,95 \pm 14,34$ & $57,51 \pm 13,23$ & $55,60 \pm 13,29$ \\
\hline $\mathrm{P}$ & $\mathrm{p}\left(\mathrm{T}_{0}\right)\left(\mathrm{T}_{2}\right)=0,001$ & $\mathrm{p}\left(\mathrm{T}_{0}\right)\left(\mathrm{T}_{8}\right)=0,000$ & $\mathrm{p}\left(\mathrm{T}_{0}\right)\left(\mathrm{T}_{\text {off }}\right)=0,000$ & $\mathrm{p}\left(\mathrm{T}_{8}\right)\left(\mathrm{T}_{\text {off }}\right)=0,249$ \\
\hline
\end{tabular}

Giá trị trung bình chỉ số $\mathrm{S}_{\bar{V}} \mathrm{O}_{2}$ giảm dần từ thời điểm $\mathrm{T}_{0}$ dến $\mathrm{T}_{\text {off }}(>55 \%)$; Sự khác biệt giá trị $\mathrm{S} \mathrm{O}_{2}-\mathrm{TB}$ thời điểm trước và sau mổ là có ý nghĩa thống kê $(\mathrm{p}<0,001)$.

- Kết quả thời gian hỗ trọ hô hấp bằng thở máy

\begin{tabular}{|l|c|c|}
\hline \multicolumn{1}{|c|}{ Thời gian thở máy } & Kết quả & $\mathrm{P}$ \\
\hline Thời gian thở máy trung bình & $22,56 \pm 30,04$ & \\
\hline Thời gian thở máy $\leq 48 \mathrm{~h}(\min =5)$ & $105 ;(93,8 \%)$ & \multirow{2}{*}{$\mathrm{P}=0,000$} \\
\hline Thời gian thở máy $>48 \mathrm{~h}(\max =192)$ & $7 ;(6,2 \%)$ & \\
\hline
\end{tabular}

Thời gian thở máy ngắn nhất là 5 giờ, dài nhất là 192 giờ (08 ngày), trung bình là 22,56 giờ;93,8\% có thời gian thở máy $\leq 48 \mathrm{~h}$; và $6,2 \%$ có thời gian thở máy $>48 \mathrm{~h}$. 
- Đồ thị ROC biểu diễn biến thiên giá trị SV̄O $O_{2}$ theo thời gian thở máy
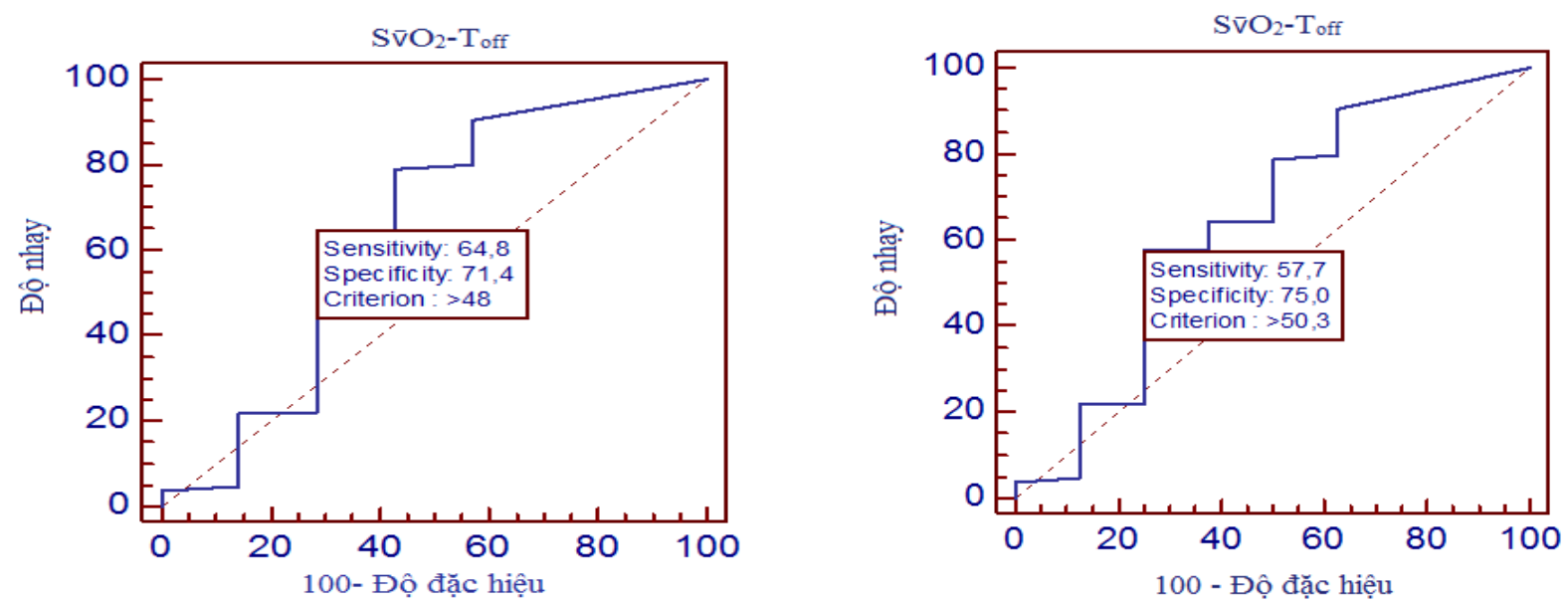

Giá trị, tọa độ tiêu chuẩn của đường ROC biến thiên $\mathrm{SV}_{\mathrm{O}} \mathrm{O}_{2}$ theo thời gian thở máy.

\begin{tabular}{|c|c|c|c|c|}
\hline Tiêu chuẩn & Độ nhạy & $95 \%$ KTC & Độ đặc hiệu & $95 \%$ KTC \\
\hline$>47,9$ & 64,76 & $54,8-73,8$ & 57,14 & $18,4-90,1$ \\
\hline$>48 *$ & 64,76 & $54,8-73,8$ & 71,43 & $29,0-96,3$ \\
\hline$>48,5$ & 63,81 & $53,9-73,0$ & 71,43 & $29,0-96,3$ \\
\hline \multicolumn{2}{|c|}{ Diện tích dưới đường ROC (AUC) $=0,652$} & \multicolumn{2}{|c|}{ P (Area=0.5)=0,1164 } \\
\hline
\end{tabular}

Diện tích bên dưới đường $\mathrm{ROC}$ chỉ điểm biến thiên giá trị $\mathrm{S} \mathrm{V}_{2}$ theo thời gian thở máy $\mathrm{AUC}=0,652$ $(\mathrm{p}=0,1164)$, có điểm cắt cut-off $>48 \%$ với độ nhạy là $64,76(\mathrm{KTC}=54,8-73,8)$, và độ đặc hiệu là 71,43 $(\mathrm{KTC}=29,0-96,3)$.

- Kết quả thời gian điều trị tại khoa hồi súc

\begin{tabular}{|l|c|c|}
\hline Thời gian điều trị tại hồi sức & Kết quả & $\mathrm{P}$ \\
\hline Thời gian hồi sức trung bình & $50,88 \pm 34,89$ & \\
\hline Thời gian hồi sức $\leq 72 \mathrm{~h}(\min =18)$ & $104 ;(92,9 \%)$ & \multirow{2}{*}{$\mathrm{P}=0,001$} \\
\hline Thời gian hồi sức $>72 \mathrm{~h}(\max =240)$ & $8 ;(7,1 \%)$ & \\
\hline
\end{tabular}

Thời gian điều trị ở hồi sức ngắn nhất là 18 giờ, dài nhất 240 giờ (10 ngày), thời gian trung bình là 50,88 giờ; $92,9 \%$ bệnh nhân có thời gian điều trị ở hồi sức $\leq 72 \mathrm{~h}$, và $7,1 \%$ bệnh nhân có thời gian điều trị ở hồi sức kéo dài trên $>72 \mathrm{~h}$.

Bảng giá trị và tọa độ tiêu chuẩn của đường cong $\mathrm{ROC}$ biểu diễn sự biến thiên giá trị $\mathrm{S}_{\mathrm{v}} \mathrm{O}_{2}$ theo thời gian điều trị tại hồi sức

\begin{tabular}{|c|c|c|c|c|}
\hline Tiêu chuẩn & Độ nhạy & $95 \%$ KTC & Độ đặc hiệu & $95 \%$ KTC \\
\hline$>50,2$ & 57,69 & $47,6-67,3$ & 62,50 & $24,5-91,5$ \\
\hline$>50,3 *$ & 57,69 & $47,6-67,3$ & 75,00 & $34,9-96,8$ \\
\hline$>51$ & 56,73 & $46,7-66,4$ & 75,00 & $34,9-96,8$ \\
\hline \multicolumn{4}{|c|}{ Diện tích dưới đường cong ROC (AUC) } \\
\hline \multicolumn{3}{|c|}{ P Area=0.5) } & 0,642 \\
\hline
\end{tabular}

- Diện tích bên dưới đường $\mathrm{ROC}$ chỉ điểm biến thiên giá trị $\mathrm{SV}_{2} \mathrm{O}_{2}$ theo thời gian hồi sức $\mathrm{AUC}=0,642$ $(\mathrm{p}=0,1248)$, có điểm cắt tối ưu cut-off $=50,3 \%$ vớiđộ nhạy là $57,69(\mathrm{KTC}=47,6-67,3)$, và độ đặc hiệu là 75,00 $(\mathrm{KTC}=34,9-96,8)$. 


\section{BÀN LUẬN}

\section{1. Đặc điểm nhóm nghiên cứu}

\section{- Độ tuổi và giới tính}

Bệnh nhân nghiên cứu của chúng tôi có tuổi trung bình là 46,69 $\pm 12,57$ tuổi, nhỏ nhất là 18 tuổi, lớn nhất là 78 tuổi. Đa số bệnh nhân có độ tuổi $<60$ tuổi chiếm tỷ lệ $85,7 \%$, những bệnh nhân có độ tuổi $\geq 60$ tuổi chiếm tỷ lệ $14,3 \%$ (bảng 3.1).

Johnas và cộng sự [2] nghiên cứu vai trò chỉ điểm của bão hòa oxy máu tĩnh mạch trộn $\mathrm{SV} \mathrm{O}_{2}$ về tình trạng huyết động và mức độ suy tim ở các bệnh nhân mổ tim có độ tuổi trung bình khá cao $(69 \pm 10$ tuổi $)$ trên nhóm bệnh nhân phẫu thuật thay van động mạch chủ có tiên lượng khả quan ở giai đoạn hồi sức sau mổ khi giá trị $\mathrm{S} \overline{\mathrm{V}} \mathrm{O}_{2} \geq 55 \%$. Những bệnh nhân có nguy cơ phẫu thuật tim cao như suy tim NYHA III-IV và nguy cơ theo đánh giá của EuroSCORE (trong đó tuổi $\geq 60$ là $1 \mathrm{YTNC}$ ) thì giá trị $\mathrm{S}_{\mathrm{V}} \mathrm{O}_{2}<55 \%$. Nghiên cứu của chúng tôi ở những bệnh nhân phẫu thuật tim có nguy cơ cao có độ tuổi trung bình thấp hơn nhưng kết quả giá trị $\mathrm{SV} \mathrm{O}_{2}$ trung bình là $55,60 \pm 13,29 \%$ khá tương đồng với kết quả của tác giả này.

\section{- Các yếu tố nguy co truớc mổ tim}

Những biến cố tim mạch thường xảy ra trong mổ tim khi có yếu cố nguy cơ thông thường theo EuroSCORE như tuổi già, giới tính nữ $(28 \%)$, và thừa cân hoặc béo phì. Các bệnh lý nguy cơ gồm có tăng huyết áp $(43,6 \%)$, đái đường $(16,7 \%)$, bệnh động mạch ngoài tim $(2,9 \%)$, suy thận mạn $(3,5 \%)$, bệnh phổi mạn tính $(3,9 \%)$, tiền sử phẫu thuật tim $(7,3 \%)$, và giảm chức năng thất trái $(31,4 \%)$. Bảng sau trình một số đặc điểm tương đồng và những điểm khác biệt về các yếu tố nguy cơ trong phẫu thuật tim giữa nghiên cứu EuroSCORE và của chúng tôi.

\section{Bảng 4.1. Các yếu tố nguy cơ trước mổ tim}

\begin{tabular}{|l|c|c|}
\hline \multicolumn{1}{|c|}{ Yếu tố nguy co } & $\begin{array}{c}\text { Nghiên cứu } \\
\text { EuroSCORE }\end{array}$ & Chúng tôi \\
\hline $\begin{array}{l}\text { Suy tim trước mổ } \\
\text { (NYHA.III-IV) }\end{array}$ & $13,7 \%$ & $81,3 \%$ \\
\hline $\begin{array}{l}\text { Phân suất tống máu } \\
\text { giảm EF }<50 \%\end{array}$ & $31,4 \%$ & $32,1 \%$ \\
\hline $\begin{array}{l}\text { Tăng áp phổi nặng } \\
\text { PASP } \geq 55 \mathrm{mmHg}\end{array}$ & $16,5 \%$ & $27,7 \%$ \\
\hline
\end{tabular}

\begin{tabular}{|l|c|c|}
\hline $\begin{array}{l}\text { Nhồi máu cơ tim mới } \\
(<90 \text { ngày })\end{array}$ & $15 \%$ & $3,6 \%$ \\
\hline $\begin{array}{l}\text { Rối loạn chức năng } \\
\text { tạng (thận, gan) }\end{array}$ & $3,5 \%$ & $8,9 \%$ \\
\hline Tuổi $\geq 60$ & $28 \%$ & $14,3 \%$ \\
\hline
\end{tabular}

- Đặc điểm các loại hình phẫu thuật tim

Trong nghiên cứu của chúng tôi, loại hình phẫu thuật bệnh van tim là chủ yếu chiếm $96,4 \%$. Loại hình phẫu thuật tim có nguy cơ cao chiếm tỷ lệ $47,33 \%$, gồm những phẫu thuật can thiệp nhiều tổn thương tim phức tạp cần thời gian cặp động mạch chủ và thời gian tuần hoàn ngoài cơ thể kéo dài như can thiệp đồng thời $\geq 02$ van tim chiếm $34,80 \%$, phẫu thuật bắc nhiều cầu chủ - vành, hoặc loại phẫu thuật can thiệp đồng thời vừa van tim lẫn động mạch vành. Có $7,14 \%$ số bệnh nhân được phẫu thuật tim lần 2 , hoặc lần 3 . Có những bệnh nhân mặc dù không quá nặng nhưng có tiền sử phẫu thuật tim vốn tiềm ẩn nguy cơ cao vì đòi hỏi phẫu tích gỡ dính nhiều, thao tác ngoại khoa tỳ đè chèn ép tim nhiều hơn, đòi hỏi thời gian mổ kéo dài và biến chứng chảy máu sau mổ cũng xảy ra với tần suất nhiều hơn.

\section{2. Đo lường giá trị của chỉ số $S \bar{v} O_{2}$ và kết quả điều trị}

- Kết quả đo lường giá trị của chỉ số $S \bar{v} \mathrm{O}_{2}$

Kết quả của nghiên cứu của Holm và cộng sự [7] cho thấy những bệnh nhân phẫu thuật động mạch vành có giá trị $\mathrm{S} \mathrm{O}_{2}<60 \%$ thường có kết quả ngắn và dài hạn là không tốt, và tăng tần suất xuất hiện các biến chứng ở giai đoạn sau mổ, và việc theo dõi giá trị $\mathrm{S} \overline{\mathrm{V}} \mathrm{O}_{2}$ giúp tiên lượng kết quả phẫu thuật.

Điểm khác biệt nổi bật trong kết quả nghiên cứu của chúng tôi là thực hiện cho những bệnh nhân nặng có nguy cơ cao cho nên chỉ số $\mathrm{S} \mathrm{O}_{2}$ giai đoạn sau mổ giảm thấp khác biệt so với tác giả trên.Biến thiên giá trị $\mathrm{S} \mathrm{O}_{2}-\mathrm{TB}$ có $\mathrm{xu}$ hướng giảm dần từ thời điểm ban đầu sau khởi mê khi người bệnh đã được thông khí nhân tạo và có hoạt động chuyển hóa giảm nên $\mathrm{SV} \mathrm{O}_{2}$ là cao nhất $\left(\mathrm{SV} \mathrm{O}_{2}-\mathrm{TB}_{\mathrm{T} 0}=73,97 \pm 7,75 \%\right)$. Ở thời điểm 2 giờ sau mổthường còn tác dụng của thuốc gây mê có tác dụng giảm chuyển hóa đồng thời duy trì thông khí nhân tạo chủ động, cũng như được hỗ trợ thuốc tăng co bóp tim làm tăng tiêu thụ oxy cho nên giá trị $\mathrm{S} \mathrm{O}_{2}$ có giảm nhưng vẫn duy trì ở mức cho phép $\left(\mathrm{S}_{\bar{V}} \mathrm{O}_{2}-\mathrm{TB}_{\mathrm{T} 2}=68,95 \pm 14,34 \%\right)$. Thời điểm 8 giờ sau mổ là khi người bệnh đã hồi tỉnh và chịu tác động 
phẫu thuật nhiều nhất với tăng chuyển hóa; đã cai máy thở cho nên $\mathrm{S} \bar{v} \mathrm{O}_{2}$ giảm $\left(\mathrm{S}_{\bar{V}} \mathrm{O}_{2}-\mathrm{TB}_{\mathrm{T} 8}=57,51 \pm 13,23 \%\right)$. Ở thời điểm khảo sát sau cùng khi người bệnh đã hoàn toàn ổn định huyết động và đã được cai máy thở thậm chí được tập vận động sớm để chuyển ra khỏi phòng hồi sức có giá trị $\mathrm{SV}_{2}$ là thấp nhất $\left(\mathrm{SV} \mathrm{O}_{2}\right.$ $\mathrm{TB}_{\text {Toff }}=55,60 \pm 13,29 \%$ ).

\section{- Kết quả thời gian hỗ trợ hô hấp bằng thở máy}

Những bệnh nhân trong nghiên cứu này có thời gian thở máy ngắn nhất là 5 giờ,dài nhất là 192 giờ (08 ngày), thời gian thở máy trung bình là 22,56 giờ ( $<01$ ngày ngày). Có $93,8 \%$ bệnh nhân có thời gian thở máy $\leq 48 \mathrm{~h} ; 6,2 \%$ có thời gian thở máy $>48 \mathrm{~h}$.Đồ thị ROC biểu diễn biến thiên giá trị $\mathrm{S} \overline{\mathrm{V}} \mathrm{O}_{2}$ theo thời gian thở máyvà bảng giá trị, tọa độ tiêu chuẩn của đường ROC biến thiên $\mathrm{SV}_{2}$ theo thời gian thở máycho thấy diện tích bên dưới đường $\mathrm{ROC}$ chỉ điểm biến thiên giá trị $\mathrm{SV}_{2}$ theo thời gian thở máy $\mathrm{AUC}=0,652(\mathrm{p}=0,1164)$, có điểm cắt tối ưu $>48 \%$ với độ nhạy là 64,76 $(\mathrm{KTC}=54,8-73,8)$, và độ đặc hiệu là 71,43 $(\mathrm{KTC}=29,0-96,3)$.

- Kết quả thời gian điều trị tại phòng hồi súc

Thời gian điều trị ở hồi sức ngắn nhất là 18 giờ, dài nhất 240 giờ ( 10 ngày), thời gian trung bình là 50,88 giờ; $92,9 \%$ bệnh nhân có thời gian điều trị ở hồi sức $\leq 72 \mathrm{~h}$, và $7,1 \%$ bệnh nhân có thời gian điều trị ở hồi sức kéo dài trên $>72 \mathrm{~h}$. Đồ thị ROC biểu diễn biến thiên giá trị $\mathrm{S} \overline{\mathrm{V}} \mathrm{O}_{2}$ theo thời gian điều trị ở hồi sức và bảng giá trị và tọa độ tiêu chuẩn của đường cong ROC biểu diễn sự biến thiên giá trị $\mathrm{S} \overline{\mathrm{O}} \mathrm{O}_{2}$ theo thời gian điều trị tại hồi sức cho thấy diện tích bên dưới đường $\mathrm{ROC}$ chỉ điểm biến thiên giá trị $\mathrm{S} \mathrm{O}_{2}$ theo thời gian hồi sức $\mathrm{AUC}=0,642$ $(\mathrm{p}=0,1248)$, có điểm cắt tối ưu tối ưu là $50,3 \%$ vớiđộ nhạy là $57,69(\mathrm{KTC}=47,6$ - 67,3), và độ đặc hiệu là 75,00 (KTC=34,9 - 96,8).

\section{KẾT LUẬA}

Qua nghiên cứu sự biến thiên giá trị các chỉ số oxy hóa ở những bệnh nhân phẫu thuật tim có nguy cơ cao chúng tôi có một số kết luận như sau:

- Giá trị của chỉ số $\mathrm{S} \square \mathrm{O} 2 \geq 55 \%$ là chỉ điểm tiên lượng điều trị huyết động cho những bệnh nhân phẫu thuật tim có nguy cơ cao, để đảm bảo duy trì cân bằng giữa cung cấp và tiêu thụ oxy của cơ thể ở giai đoạn hồi sức sau mổ.

- Hồi sức huyết động dưới hướng dẫn bởi các chỉ số oxy hóa nói trên ở những bệnh nhân này giúp cải thiện với giảm thời gian thở máy $(22,56 \pm 30,04$ giờ $)$, và thời gian điều trị hồi sức $(50,88 \pm 34,89$ giờ). Giá trị của chỉ số $\mathrm{SV}_{2} \geq 48 \%$; và $\mathrm{S} \mathrm{V}_{2} \geq 50,2 \%$ có ý nghĩa tiên lượng điều trị huyết động trong việc cai máy thở và cải thiện điều trị ở phòng hồi sức.

\section{TÀI LIỆU THAM KHẢO}

- Cairns C. B., et al., "Evidence for early supply independent mitochondrial dysfunction in patients developingmultiple organ failure after trauma," Journal of Trauma-Injury Infection \& Critical Care, vol. 42, no. 3, pp.532-536, 1997.

- Cohn S. M., F. A. Moore et al., "Tissue oxygen saturation predicts the development of organ dysfunction during traumatic shock resuscitation," Journal of Trauma-Injury Infection \& Critical Care, vol. 62, no. 1, pp. 44-55, 2007.

- Lima A., van Bommel J., and Bakker J., "Low tissue oxygen saturation at the end of early goal-directed therapy is associated with worse outcome in critically ill patients," Critical Care, vol. 13, supplement 5, article S13, 2009.

- Lima A., van Genderen M. E., Klijn E., Bakker J., and van Bommel J., "Peripheral vasoconstriction influences thenar oxygen saturation as measured by near-infrared spectroscopy," Intensive Care Medicine, vol. 38, no. 4, pp. 606-611, 2012.

- Lipcsey M., Woinarski N. C. Z., and Bellomo R., "Near infrared spectroscopy (NIRS) of the thenar eminence in anesthesia and intensive care," Annals of Intensive Care, vol. 2, article 11, 2012.

- Nguyen H. B., "Central venous oxygen saturation: not easily replaced," Critical Care Medicine, vol. 41, no. 6, pp. 1570-1571, 2013.

- Pinsky M. R., "Beyond global oxygen supplydemand relations: in search of measures of dysoxia,"Applied Physiology in Intensive Care Medicine, vol. 2, pp. 319-321, 2012.

- Santora R. J. andMoore F. A., "Monitoring trauma and intensive care unit resuscitation with tissue hemoglobin oxygen saturation," Critical Care, vol. 13, supplement 5, article S10, 2009.

- Whittemore R. and Knafl K., "The integrative review: updated methodology," Journal of Advanced Nursing, vol. 52, no. 5, pp. 546553, 2005. 